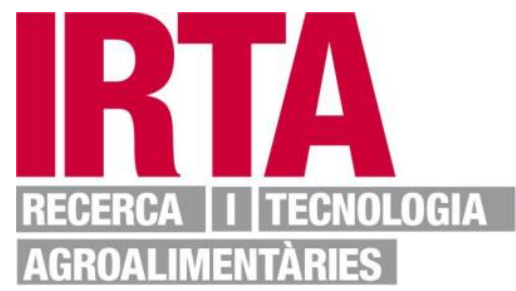

This document is a postprint version of an article published in Journal of Cleaner Production (C) Elsevier after peer review. To access the final edited and published work see https://doi.org/10.1016/i.jclepro.2018.08.212 


\title{
Valuing social sustainability in agriculture: an approach based on social outputs' shadow prices
}

\author{
Amer Ait Sidhoum ${ }^{1}$ \\ Centre de Recerca en Economia i Desenvolupament Agroalimentaris (CREDA)-UPC-IRTA, Parc Mediterrani de la \\ Tecnologia, Edifici ESAB, C/Esteve Terrades, 8, 08860 Castelldefels, Barcelona, Spain. \\ Email: amer.ahit-sidhoum@upc.edu
}

${ }^{1}$ Corresponding author: Amer Ait Sidhoum, Tel: (+34) 935-521-209, Fax: (+34) 935-521-121.

Email: amer.ait-sidhoum@upc.edu 


\section{Abstract}

2 Interest in sustainability has gained ground among practitioners, academics and policy-makers due to 3 growing stakeholders' awareness of environmental and social concerns. This is particularly true for

4 agriculture. However, relatively little research has been conducted on the quantification of social 5 sustainability and the contribution of social issues to the agricultural production efficiency. This paper 6 proposes a framework based on state-contingent outputs to compute shadow prices of social outputs.

7 Our methodological approach is based on the directional distance function and illustrated using a 8 farm-level dataset from a sample of Catalan arable crop farms in 2015. Our results indicate that in the 9 sample of 180 farms included in the analysis, efficiency scores are relatively high for the three 10 alternative states of the nature considered in our state-contingent analysis. In addition, our findings 11 show that social outputs' shadow prices are positive, indicating that producing more social outputs is 12 considered as great value to the farm. For the efficient farms, the social outputs' shadow prices are 13 contingent upon on the state of nature, in a way that social outputs' shadow prices increase with the 14 improvement in crop growth conditions. These results have implications in terms of EU farm payment 15 redistribution.

17 Keywords: Social sustainability, Agriculture, Data envelopment analysis, Shadow prices 
2 Agriculture plays a major role in providing humanity's basic needs for food, feed, fiber and biofuel,

3 thus participating in the economic development of countries, but also contributes to the production of 4 a valuable range of non-marketable goods. These include public goods such as landscapes, food safety 5 and local food security, farmland biodiversity and enhancing the quality of the environment, as well 6 as private goods such as farmers' well-being. In the European Union (EU), the current challenge is to 7 design the EU agricultural policy, namely the Common Agricultural Policy (CAP) in a way that it 8 helps reach a satisfactory level of joint provision of public (non-marketable) goods and private 9 (marketable) goods. An agricultural policy that encourages the production of marketable goods to the 10 detriment of the public goods is no longer aligned with society's expectation. The expectations 11 nowadays are oriented towards a sustainable agriculture characterized by a competitive production 12 process that ensures the economic viability of the sector while preserving the environment and 13 improving the quality of life of farmers, farm workers and society (Franz Fischler, 2002). In this context, assessments of how sustainable agriculture is, are common and various 15 approaches are available. One approach is to assess sustainable performance with the methods 16 available in the efficiency and productivity measurement literature. There are numerous examples 17 pertaining to sustainable farming and firm performance literature dealing with environmental impacts 18 of economic activities (Ağan et al., 2016; Battini et al., 2016; Chen et al., 2016; Fathollahi et al., 19 2018; Mariantonietta et al., 2018). However, fewer studies have investigated the social dimension of 20 performance (Ferri and Pedrini, 2018; Pashaei Kamali et al., 2017) although it is now widely accepted 21 that performance should include social issues. Given the increased attention paid to social issues in 22 sustainable farming, earlier literature has been dedicated to examining the "why" question, that is, 23 why farmers need to integrate social issues in their farming practices (Allen et al., 1991; Thompson 24 and Wiggins, 2002). Little is available regarding the "what" question, that is, what is the social 25 dimension and what are the social indicators that should be taken into account to quantify the social 
1 dimension of sustainability (Van Calker et al., 2007).The question of "how" social outputs from

2 agricultural production technologies can be quantified and priced has not been investigated so far. ${ }^{2}$

4 prices of social outputs, more precisely shadow prices (i.e. prices that are not directly available from

5 market transactions), by allowing for the stochastic nature of agricultural production that is to say for

6 production uncertainty. Assessing the performance of social dimension and production uncertainty

7 requires data that are not usually available, especially at farm level. We elicit this information through

8 a survey conducted to a sample of Catalan farms.

9 By doing so, we contribute to the existing knowledge on what is the social dimension of 10 sustainable farming and provide an empirical illustration of how social outputs can be quantified.

11 Further, a sound measure of the agricultural social outputs will provide a better understanding of 12 farm-level decision-making processes, which is a necessary pre-requisite for policy-makers interested

13 in sustainable farming. In the EU the new CAP programming (2014-2020), agreed upon in 2013,

14 aims at promoting the joint provision of public and private goods (European Commission, 2013).

15 Hence, providing measures of social outputs' shadow prices that account for the stochastic nature of

16 the production technology are important for the implementation and effectiveness of public

17 agricultural policies that aim to improve sustainable farming practices.

18 The remainder of this article is organized as follows. The next section presents a literature review.

19 The third section focuses on methodological issues. The fourth section focuses on results and some 20 implications on sustainability practices. The paper ends with concluding remarks and some directions 21 for future research.

\footnotetext{
${ }^{1}$ The study therefore contributes to theory by identifying "how" (Whetten, 1989) social outputs of farm performance can be quantified.

${ }^{2}$ Only recently, Chambers and Serra (2016) have proposed a measure of firm efficiency that allows for corporate social responsibility activities.
} 
2 Providing non-marketable goods from agriculture and forestry is needed and chart out long-term 3 pathways to achieve sustainable development (European Commission, 2013). The current challenge 4 is to identify key indicators that reflect public goods. Cooper et al. (2009, p. 15) suggest that the most 5 significant public goods from agriculture are agricultural landscapes, farmland biodiversity, water 6 quality and water availability, soil functionality, carbon storage and climate stability, greenhouse gas 7 emissions, air quality, resilience to flooding and resilience to fire, and additional social public goods, 8 including rural vitality, food security, farm animal welfare and animal health. Vanni (2014) classified 9 public goods into two categories: environmental public goods and social public goods. The first 10 category includes farmland biodiversity, water availability and quality, resilience to flooding and fire,

11 climate, agricultural landscape, while the social public goods category covers indicators that revolve 12 around farming and rural life, such as farm animal welfare and health, rural vitality and food security.

13 Social goods include not only the above-mentioned public goods, but also some private (non14 marketable) goods such as farmers' quality of life. The available literature agrees that the provision 15 of social public goods is strongly associated with social sustainability (Diazabakana et al., 2014). 16 However, considerable ambiguity surrounds the quantification of the social dimension of 17 sustainability (Dempsey et al., 2011; Missimer et al., 2010; Murphy, 2012; Rafiaani et al., 2018; Van 18 Calker et al., 2007), whose analysis is less advanced than the other two pillars of sustainability (Badri 19 Ahmadi et al., 2017; Cuthill, 2010). While achieving sustainable development requires a balanced integration of the environmental, economic, and social dimensions (Seuring and Müller, 2008). Lebacq et al. (2013) suggest that social dimension involves a set of indicators that include 22 education, working conditions, well-being and health, quality of rural areas, acceptable agricultural 23 practices and product quality. Van Calker et al. (2007) suggest that social dimension of dairy farming 24 involves a combination of working conditions and societal sustainability which includes food safety, 25 animal welfare, and landscape quality. Phelan et al. (2017, p. 303) assess the social dimension of 26 agricultural and regional communities which are affected by Coal Seam Gas in Australia. Using 5- 
1

2

point Likert type scales, the authors measure social dimension by considering the following items: (i) access to healthy natural environment, (ii) access to infrastructure and economic opportunities, (iii) equity and governance, (iv) social cohesion, and (v) community actualization. While current definitions of sustainable agriculture focus mainly on environmental issues, a commonly accepted definition of the social dimension does not yet exist (Allen et al., 1991). Different other research papers have aimed at developing social sustainability indicators (Boström, 2010; GRI, 2015; Landorf, 2011; Serra and Poli, 2015; Staniškienè and Stankevičiūtè, 2018; Thomsen and King, 2008), these often depend on the specific problem under assessment. A summary of the main social sustainability indicators of the articles reviewed are presented in table 1.

While, a commonly accepted definition of the social dimension does not yet exist (Allen et al., 1991), there appears to be some consensus across the existing literature on the relevant social indicators to consider, the indicators are classified in two categories: social indicators which are associated to farm community (such as farmers well-being and working conditions), the second category of social indicators are related to society as a whole (quality of rural areas, contribution to local employment and product responsibility) (Diazabakana et al., 2014). Measuring social dimension is problematic as it is difficult to make these indicators objective and quantifiable. This is due to the dominant part of the subjective factors that affect social sustainability (Edum-Fotwe and Price, 2009). Several authors share the same point of view, suggesting that social sustainability tend to be more subjective (Boström, 2012; Dillard et al., 2008). Self-reported qualitative information, especially Likert scale have been very useful for rating subjective factors that has precedence within the sustainability literature (Barr et al., 2011; Chang et al., 2018; Chung et al., 2016; Kalsoom and Khanam, 2017; Law and Gunasekaran, 2012; Lozano et al., 2016; Maletič et al., 2016; Sellers-Rubio and Nicolau-Gonzalbez, 2016; Vintró et al., 2014; Xiao et al., 2018). 
Table 1 Literature review on social sustainability indicators

\begin{tabular}{|c|c|c|c|c|}
\hline Authors & Type & Indicators of Social dimension & $\begin{array}{l}\text { Indicators measurement } \\
\text { tool used in the study }\end{array}$ & Empirical application \\
\hline Lebacq et al.( 2013) & Conceptual & $\begin{array}{l}\text { Education, working conditions, quality of life, } \\
\text { multifunctionality, acceptable agricultural } \\
\text { practices, quality of products }\end{array}$ & Mainly qualitative & - \\
\hline Van Calker et al. (2007) & Empirical & $\begin{array}{l}\text { working conditions and societal sustainability } \\
\text { (such as food safety, animal welfare, and } \\
\text { landscape quality) }\end{array}$ & $\begin{array}{l}\text { Qualitative and } \\
\text { quantitative }\end{array}$ & $\begin{array}{l}\text { Conventional and organic } \\
\text { Dutch dairy farming }\end{array}$ \\
\hline Phelan et al. (2017) & Empirical & $\begin{array}{l}\text { Access to healthy natural environment, access } \\
\text { to infrastructure and economic opportunities, } \\
\text { equity and governance, social cohesion, and } \\
\text { community actualization. }\end{array}$ & Qualitative & $\begin{array}{c}\text { Residents affected by coal } \\
\text { seam gas. Surat Basin region } \\
\text { of Southeast Queensland, } \\
\text { Australia } \\
\end{array}$ \\
\hline Boström (2010) & Empirical & $\begin{array}{l}\text { workers, local communities, and indigenous } \\
\text { peoples, Local organization, empowerment, } \\
\text { and employment, Communication }\end{array}$ & Qualitative & $\begin{array}{l}\text { Forest Stewardship Council, } \\
\text { Sweden }\end{array}$ \\
\hline Thomsen and King (2008) & Empirical & Social aspects related to business & Qualitative & $\begin{array}{l}\text { Small business owners in } \\
\text { Portland, U.S. }\end{array}$ \\
\hline $\begin{array}{l}\text { Global Reporting Initiative } \\
\text { (GRI) (2015) }\end{array}$ & Conceptual & $\begin{array}{l}\text { Labour practices and decent work, Human } \\
\text { rights, Society and Product responsibility }\end{array}$ & $\begin{array}{c}\text { Qualitative and } \\
\text { quantitative }\end{array}$ & - \\
\hline $\begin{array}{l}\text { Staniškienè and } \\
\text { Stankevičiūtè (2018) }\end{array}$ & Empirical & $\begin{array}{l}\text { Employee participation, Employee } \\
\text { cooperation, Equal opportunities, Employee } \\
\text { potential development, Health and safety, } \\
\text { External partnership }\end{array}$ & $\begin{array}{l}\text { Qualitative and } \\
\text { Quantitative }\end{array}$ & $\begin{array}{l}\text { Lithuanian Association of } \\
\text { Responsible Business }\end{array}$ \\
\hline Landorf (2011) & Empirical & $\begin{array}{l}\text { Social equity, Social coherence and Needs } \\
\text { satisfaction }\end{array}$ & $\begin{array}{c}\text { Qualitative and } \\
\text { Quantitative }\end{array}$ & $\begin{array}{c}\text { City of Broken Hill, } \\
\text { Australia } \\
\end{array}$ \\
\hline Serra and Poli (2015) & Empirical & Social capital & Qualitative & $\begin{array}{l}\text { Small farms in Maharashtra, } \\
\text { India }\end{array}$ \\
\hline
\end{tabular}



outcomes provided by self-rating from a sample of Catalan farmers. A four-point Likert scale was adopted, and farmers were asked to evaluate their relative levels of agreement/disagreement with social outcomes (table 2).

Given the stochastic nature of the agricultural economic activity in particular due to climate variability, it is crucial to represent such analysis in a context of production uncertainty (O'Donnell et al., 2010). We rely on the work of Chambers and Quiggin $(2000,1998)$ and use the state-contingent approach to model production under uncertainty. This approach, which has its origins in Arrow and Debreu (1954), considers that outputs are conditional on the state of nature in which they are realized. The state-contingent approach offers two main advantages. First, I does not require any a priori probabilistic assessment of production; second, its application does not depend on the decision maker's attitudes toward risk. Yet to date only relatively few studies ${ }^{3}$ have applied the state-contingent technology in production and efficiency analyses. (Chambers et al., 2014; Serra et al., 2014).

O'Donnell and Griffiths (2006) propose an application of the state-contingent framework to the estimation of production frontiers. Chavas (2008) and Serra et al. (2010) estimated the cost functions for stochastic technology by defining a two-dimensional state space using aggregated data from the United States. Assessing Finnish agricultural production under inefficiency and uncertainty without regard to the nature of producer risk preferences, Nauges et al. (2011) used state-contingent model to estimate a flexible production model. Serra et al. (2014) propose farm-level technical and environmental efficiency measures that allow for the stochastic conditions under which production takes place using a state-contingent approach. There are very few shadow prices studies that have applied state-contingent framework. Recently, Chambers et al. (2014) used a state-contingent DEA framework to account for the stochastic nature of agricultural production and obtain state-contingent shadow prices for nitrogen pollution for a sample of Catalan farms.

\footnotetext{
${ }^{3}$ The lack of appropriate datasets, which require ex-ante information, may explain the few empirical applications dealing with the subject.
} 
Likert scale value

\begin{tabular}{|c|c|c|c|c|}
\hline Statement & $\begin{array}{l}\text { STRONGLY } \\
\text { AGREE }\end{array}$ & AGREE & DISAGREE & $\begin{array}{l}\text { STRONGLY } \\
\text { DISAGREE }\end{array}$ \\
\hline $\begin{array}{l}\text { Agricultural activities of my farm contribute positively to the landscape } \\
\text { quality }\end{array}$ & 4 & 3 & 2 & 1 \\
\hline Our farm products are safe for the health of the consumers & 4 & 3 & 2 & 1 \\
\hline Products from the farm contribute to food security in the region & 4 & 3 & 2 & 1 \\
\hline Our farm contributes positively to the local economy & 4 & 3 & 2 & 1 \\
\hline Our farm contributes to the social fabric of rural communities & 4 & 3 & 2 & 1 \\
\hline $\begin{array}{l}\text { Our farm contributes to maintain basic services (schools, health facilities, etc } \\
\text {...) in rural areas }\end{array}$ & 4 & 3 & 2 & 1 \\
\hline Our farm helps to reduce the local unemployment & 4 & 3 & 2 & 1 \\
\hline
\end{tabular}


Agricultural production results from an interaction of an economic and social system in a

2 natural environment, which implies a flow of different materials. In this context, if the production

3 process does not satisfy the physical laws, especially materials balance concerns, modeling biases

4 and erroneous inferences are likely to appear (Førsund, 2009; Murty et al., 2012). There have been

5 few studies reported that integrate materials balance principle into economics analysis. Its roots reside

6 in Ayres and Kneese (1969), Kneese et al. (1970) and Noll and Trijonis (1971). The essential idea is

7 that the total amount of materials in the inputs must equal the amount of materials in intended outputs

8 plus the materials in the residuals that may cause pollution.

9 As the environmental awareness has become of growing interest, environmental economics 10 studies have evolved to introduce the materials balance principle in the environmental production 11 technology (Coelli et al., 2007; Hampf and Rødseth, 2015; Hoang and Coelli, 2011; Murty et al., 12 2012; Serra et al., 2014; Welch and Barnum, 2009). Introduced by Ayres and Kneese (1969) and 13 further developed by Coelli et al. (2007) the materials balance concept is considered more tightly 14 linked to economic and environmental analysis for efficiency and productivity as the appropriate way 15 to model undesirable outputs, proposing an efficiency measures that incorporate the materials balance 16 concept in a social sustainability context has the advantage of filling the gap between the conventional 17 performance analysis and social sustainability analysis and, consequently, making a relevant step in 18 sustainability performance assessment. 
Table 3. The empirical shadow pricing analysis and advantages and disadvantages by estimation methodology

\begin{tabular}{|c|c|c|c|}
\hline Method & Advantages & Disadvantages & Study examples \\
\hline DEA/DDF & $\begin{array}{l}\text { - Does not require the imposition of a functional } \\
\text { form } \\
\text { - It can describes completely the production } \\
\text { technology and models joint production of } \\
\text { multiple outputs. } \\
\text { - Offers simplicity in calculation } \\
\text { - Flexibility in modeling } \\
\text { - Robust to misspecification issues } \\
\text { - Using state-contingent technique help to } \\
\text { circumvent the main limitation of the DEA } \\
\text { approach by representing the stochastic } \\
\text { technology in terms of state-contingent outputs. }\end{array}$ & $\begin{array}{l}\text { - As a non-parametric approach, it does not take } \\
\text { into account random error. } \\
\text { - Deals with relative efficiency measurement }\end{array}$ & $\begin{array}{l}\text { Chambers et al. (1996) } \\
\text { Lee et al. (2002) } \\
\text { Singbo et al. (2015) } \\
\text { Skevas and Serra (2017) } \\
\text { Dakpo et al. (2017) } \\
\text { Cecchini et al. (2018) } \\
\text { Wang et al. (2016) }\end{array}$ \\
\hline SFA & $\begin{array}{l}\text { - SFA uses a pre-defined functional form to } \\
\text { characterize distance function, translog and } \\
\text { quadratic forms are the most commonly used } \\
\text { - Takes statistical noise into consideration }\end{array}$ & $\begin{array}{l}\text { - Parametric approach can be biased if the } \\
\text { functional form is misspecified. } \\
\text { - Restricted to a single output variable } \\
\text { - Implementing state-contingent approach within } \\
\text { SFA could lead to high collinearity issues, this is } \\
\text { due to the important correlation between outputs } \\
\text { in the different states. }\end{array}$ & $\begin{array}{l}\text { Färe et al. (2005) } \\
\text { Aiken and Pasurka (2003) } \\
\text { Murty and Kumar (2002) } \\
\text { Xie et al. (2016) }\end{array}$ \\
\hline
\end{tabular}


There is already an extensive empirical literature estimating shadow prices of outputs using nonparametric or parametric estimations. Färe et al. (2005b) used a quadratic directional output distance function to derive shadow prices of undesirable outputs generated from a sample Electric Utilities in the U.S. Murty and Kumar (2002) used stochastic frontier models for a sample of 60 water polluting industries in India to measure water pollution abatement costs. Aiken and Pasurka (2003) estimated translog output distance function to compute shadow prices of air pollution emissions from U.S. manufacturing industries. More recently, Xie et al. (2016) estimated the shadow price of sulfur dioxide emissions in China by using the parametric quadratic directional distance function. In the nonparametric literature, Skevas and Serra (2017) used DEA directional distance function model to derive agricultural netput shadow prices for a sample of Dutch arable farms. Lee et al. (2002) also used a nonparametric directional distance function approach to calculate shadow prices of pollutants for Korea's electric power industry. Dakpo et al. (2017) used DEA to assess the efficiency adjusted for greenhouse gas emissions and compute shadow prices for sheep meat breeding farms in France. Singbo et al. (2015) used DEA framework to estimate technical efficiency and the shadow values of each input for a sample of vegetable producers in Benin. Table 3 summarizes the advantages and disadvantages of the estimation methodologies of previous articles.

As far as we know, there is only one study on shadow prices dealing with social dimension. This study considers social capital as an input similar to other conventional inputs such as labor and physical capital (Serra and Poli, 2015). Building on the state-contingent approach proposed by Chambers et al. (2014) that focuses exclusively on technical and environmental evaluation, and extending the study of Serra and Poli (2015) that estimates non-random input shadow prices, our paper takes the literature one step further by proposing an appropriate representation of the statecontingent production technologies with social outputs and computing farm-level shadow prices of social outcomes generated through agricultural activities. 
3 In this article, the assessment of social outputs' shadow prices is conducted within the methodological 4 framework of nonparametric Data Envelopment Analysis (DEA) (for basic explanations on this 5 approach see (Cooper et al., 2011) ). An output-oriented directional distance function (DDF) ((Färe 6 and Grosskopf, 2000)) is implemented to represent the technology of a sample of Catalan arable crop 7 farms and derive the efficiency scores. The Directional Distance Function (DDF) approach which is 8 a specification of the DEA, was proposed by Chambers et al. (1996) to allow for the possibility to 9 estimate production technology with multiple-inputs and multiple-outputs.. As a non-parametric 10 technique, the DDF does not requires assumptions on a specific functional form, which gives it more 11 flexibility and limits modeling biases and erroneous inferences. Because of its flexibility in the 12 estimation, the DDF is considered one of the most popular approach for measuring efficiency scores 13 from the envelopment approach, while shadow prices are derived by employing the multiplier from 14 of the DDF. stochastic production technology in terms of a state contingent approach. This approach differentiates 17 production according to the state of nature in which it is realized. Uncertainty is represented through the state space $\Omega=1 \ldots s$, randomly chosen by nature.

19 Random variables are represented by vector space $\mathbb{R}^{\Omega}$ and are differentiated from non-random 20 variables using tildes, e.g. $\tilde{y}=\left[y_{s}: s \in \Omega\right]$ is the random variable of $y$, where $y_{s} \in \mathbb{R}$ for $s \in \Omega$ 21 represents the ex-post value of $y$ if nature chooses state $s$. Several random variables are considered in our representation of the overall production 23 technology $T$. The latter is assumed to be the intersection of two different sub-technologies ${ }^{4}$ (Murty

\footnotetext{
${ }^{4}$ Murty et al., 2012 model a firm's production technology as the interaction of two sub-technologies: an intended output technology and an unintended output technology. In our study, two separate sub-technologies
} 
1 et al., 2012), namely $T^{Y}$ that models the production of random desirable outputs and $T^{S C}$ that reflects

2 the social outcomes from agricultural activities. The intersection of the two sub-technologies is 3 represented as follows:

4

$$
T=T^{Y} \cap T^{S C}
$$

The specification of the general production technology, integrating the two different subtechnologies can be represented by:

$$
T=\left\{\left(x_{n}, \tilde{q}_{k}, c_{d}, w_{a}, \tilde{z}_{k}, \tilde{y}_{m}, S c\right):\left(x_{n}, \tilde{q}_{k}, \tilde{z}_{k}, c_{d}, w_{a}\right) \text { can produce }\left(\tilde{y}_{m}, S c\right)\right\}
$$

The first step that we consider in the specification of $T$ is to ensure that it is consistent with materials-balance requirements. Thus, following previous research (Førsund, 2008, 1998; Serra et al., 2014), we consider that the applied runoff inputs ${ }^{5}$ (organic and chemical nitrogen $r_{k}$ ) equal to the amount of absorbed $\left(\tilde{q}_{k}\right)$ by the plant in the production of the desired output technology $T^{Y}$, while the remaining quantity known as nitrogen balance $\left(\tilde{z}_{k}\right)$ represents the nitrogen runoff losses that have a negative impact on the social sub-technology $T^{S C}$.

We consider the intended output sub-technology $T^{Y}$ that produce $M$ random desirable outputs, denoted by $\tilde{y} \in \mathbb{R}^{M}$ (for $m=1, \ldots M$, with $M=3$ ), by using a set of $N$ traditional nonpolluting inputs $\left(x_{n} \in \mathbb{R}^{N}, n=1, \ldots, N\right.$, where input $x_{1}$ represents land allocated to crops in hectares, $x_{2}$ measures the capital replacement value in euros, $x_{3}$ represents paid and unpaid labor in hours. Input $x_{4}$ measures the costs of energy in euros. Variable inputs include stochastic fertilizer inputs $\left(\tilde{q}_{k} \in \mathbb{R}^{K}, k=1, \ldots, K\right)$, and non-random pesticides applications $\left(c_{d} \in \mathbb{R}^{D}, d=1, \ldots, D\right)$ measured in liters. Finally, this article extends efficiency and productivity traditional measurement

are considered. One represents the production of intended or good outputs, while the second sub-technology models the production of social outputs.

${ }^{5}$ The absorbed quantity of nitrogen is state-contingent since the quantity of fertilizer absorbed by plants depends on yields and can be represented by $r_{k}=\tilde{q}_{k s}+\tilde{z}_{k s}$, where $\tilde{q}_{k s}$ is the quantity of fertilizer in input $r_{k}$ that is captured and used by the plant, and $\tilde{z}_{k s}$ represents the nitrogen runoff losses. 
1 literature by including a social input representing working conditions $\left(w_{a} \in \mathbb{R}^{A}, n=1, \ldots, A\right)$. The

2 intended output technology is thus:

$$
T^{Y}=\left\{\left(x_{n}, \tilde{q}_{k}, c_{d}, w_{a}, \tilde{z}_{k}, \tilde{y}_{m}, S c\right):\left(x_{n}, \tilde{q}_{k}, c_{d}, w_{a}\right) \text { can produce }\left(\tilde{y}_{m}\right)\right\}
$$

The social outcomes technology produces a non-random desirable social output ${ }^{6}$ denoted by $S C \in \mathbb{R}$, by using a set of non-polluting inputs $\left(x_{n} \in \mathbb{R}^{N}\right)$. Two polluting inputs are considered to have a negative impact on the social benefits generated through agricultural production. The first one consists in chemicals (pesticide, herbicide and insecticide) applications $\left(c_{d} \in \mathbb{R}^{D}\right)$ and the second one is nitrogen runoff $\left(\tilde{z}_{k} \in \mathbb{R}^{K}, k=1, \ldots, K\right)$ in kilos. It is assumed that better working conditions for farmers tend to improve the social benefits of agricultural activities. The generated social technology $T^{S c}$ can be expressed as follow:

$$
T^{S c}=\left\{\left(x_{n}, \tilde{q}_{k}, c_{d}, w_{a}, \tilde{z}_{k}, \tilde{y}_{m}, S c\right):\left(x_{n}, \tilde{z}_{k}, c_{d}, w_{a}\right) \text { can produce }(S c)\right\}
$$

The overall technology $T$ reflects the transformation process of the inputs into the random desirable outputs and the non-random social output. Regarding the disposability properties of each sub-technology, our theoretical framework is based on free disposability of desirable outputs and inputs in $T^{Y}$. The sub-process $T^{S c}$ displays strong disposability of social outputs as well as the conventional inputs $\left(x_{n} \in \mathbb{R}^{N}\right)$, while weak disposability is assumed for chemicals applications and nitrogen runoff, which implies that $c_{d}$ and $\tilde{z}_{k}$ can not be reduced without additional cost.

So far, we have theoretically defined the production technology $T$. In order to specify this within a nonparametric DEA framework, we suppose that we have a set of observations on the production practices of $I$ farms to be evaluated. By assuming a production technology with constant returns to scale, $T$ can be represented by:

\footnotetext{
${ }^{6}$ As they are qualitative factors, social outputs are measured on a Likert scale (Table 4). However, DEA models are not appropriate for non-continuous data such as Likert-scale values. As shown by Chen et al., 2015 extended DEA models for situations that Likert scale data are present. Therefore, here principal component analysis (PCA) was used beforehand to transform the Likert categorical variables into continuous variables that can be used in the DEA model (Dong et al., 2015).
} 


$$
\left\{\begin{array}{c}
T=T^{Y} \cap T^{S c}= \\
\left(x_{n}, \tilde{q}_{k}, c_{d}, w_{a}, \tilde{z}_{k}, \tilde{y}_{m}, S c\right): \tilde{y}_{m}{ }^{i} \leq \sum_{i} \lambda^{i} \tilde{y}_{m}{ }^{i}, \lambda \in \mathbb{R}_{+}^{I} \\
x_{n}{ }^{i} \geq \sum_{i} \lambda^{i} x_{n}{ }^{i}, n=1, \ldots, N \\
c_{d}{ }^{i} \geq \sum_{i} \lambda^{i} c_{d}{ }^{i} \\
\tilde{q}_{k}{ }^{i} \geq \sum_{i} \lambda^{i} \tilde{q}_{k}{ }^{i}, k=1, \ldots, K \\
w_{a}{ }^{i} \geq \sum_{i} \lambda^{i} w_{a}{ }^{i}, a=1, \ldots, A \\
\left(x_{n}, \tilde{q}_{k}, c_{d}, w_{a}, \tilde{z}_{k}, \tilde{y}_{m}, S c\right): S^{i} \leq \sum_{i} \delta^{i} S c^{i}, \delta \in \mathbb{R}_{+}^{I} \\
x_{n}{ }^{i} \geq \sum_{i} \delta^{i} x_{n}{ }^{i} n=1, \ldots, N \\
c_{d}{ }^{i}=\sum_{i} \delta^{i} c_{d}{ }^{i} \\
\tilde{z}_{k}{ }^{i}=\sum_{i} \delta^{i} \tilde{z}_{k}{ }^{i}, k=1, \ldots, K \\
w_{a}{ }^{i} \geq \sum_{i} \delta^{i} w_{a}{ }^{i}, a=1, \ldots, A
\end{array}\right.
$$

5 Where $\lambda \in \mathbb{R}_{+}^{I}$ and $\delta \in \mathbb{R}_{+}^{I}$ denote the intensity vectors, providing the weights assigned to each farm used to define the efficient reference set for the intended outputs and the social outputs, respectively. The output-oriented DEA model attempts to maximize outputs $\left(\tilde{\mathrm{y}}_{\mathrm{m}}, \mathrm{Sc}\right)$ without changing the 8 use of inputs $\left(\mathrm{x}_{\mathrm{n}}, \tilde{\mathrm{q}}_{\mathrm{k}}, \mathrm{c}_{\mathrm{d}}, \mathrm{w}_{\mathrm{a}}, \tilde{\mathrm{z}}_{\mathrm{k}}\right)$. Although DEA does not require a priori information on the 9 underlying functional forms, it does need some assumptions on how these inputs and outputs interact. 10 Our assumption for the first process $\mathrm{T}^{\mathrm{Y}}$ follows the direction in which the inequalities are expressed in Eq. 5(a). We assume that an increase in all inputs $\left(\mathrm{x}_{\mathrm{n}}, \tilde{\mathrm{q}}_{\mathrm{k}}, \mathrm{c}_{\mathrm{d}}, \mathrm{w}_{\mathrm{a}}\right)$ will increase the crop production

$12\left(\tilde{y}_{\mathrm{m}}\right)$. The representation $\mathrm{T}^{\mathrm{Sc}}$ assumes inequalities with different directions in Eq. 5(b): increasing 13 conventional inputs $\left(\mathrm{x}_{\mathrm{n}}\right)$ and improving working conditions $\left(\mathrm{w}_{\mathrm{a}}\right)$ tend to increase the production of 
1 social outputs, while adding an extra unit of chemicals use $\left(c_{d}\right)$ and nitrogen runoff $\left(\tilde{z}_{k}\right)$ will reduce

2 inhibit the ability to produce social outputs.

3

11 potential adjustments of the desirable outputs and social output to the best practice frontier, the output12 oriented DDF of the overall the production technology (Eq. 1) can be represented as:

Once a nonparametric production technology has been represented, the DDF can be used for efficiency measurement, and shadow prices can be derived from the multiplier formulation. Computing shadow prices is a method to assign an economic value to non-marketed social outcomes based on their contribution to efficiency scores. The DDF allows to simultaneously contract inputs and expand desirable outputs of a given farm using a pre-assigned direction vector (Chambers et al., 1998, 1996; Färe and Grosskopf, 2000).

Given $\vec{g}=\left(g_{y}, g_{S c}\right) \in \mathbb{R}_{+}$which represents the directional vector that measures the $\vec{D}_{(I)}\left(x_{n}, \tilde{q}_{k}, c_{d}, w_{a}, \tilde{z}_{k}, \tilde{y}_{m}, S c, \vec{g}\right)=$

$\operatorname{Max}\left\{\beta \mid\left(\tilde{y}_{m}+\beta_{1} g_{\tilde{y}_{m}}, x_{n}, \tilde{q}_{k}, c_{d}, w_{a}\right) \in T^{Y} \cap\left(S c+\beta_{2} g_{S c}, x_{n}, \tilde{z}_{k}, c_{d}, w_{a}\right) \in T^{S c}\right\}$

Where $\beta=\left(\beta_{1}, \beta_{2}\right)$ is the scaling factors vector representing inefficiency measure. The choice of directions is driven by the purpose of the study. In our case we use $g_{\tilde{y}_{m}}=\left(\tilde{y}_{m}\right)$ and $g_{S c}=(S c)$, where farmers aim to simultaneously maximize the desirable output and social output while keeping inputs constant. A data envelopment representation is used to evaluate the directional distance function (6) and can be expressed as follows:

$$
\vec{D}_{(I)}\left(x_{n}, \tilde{q}_{k}, c_{d}, w_{a}, \tilde{z}_{k}, \tilde{y}_{m}, S c, g_{\tilde{y}_{m}}, g_{S c}\right)=\vec{D}_{(I)}^{Y} \cap \vec{D}_{(I)}^{S c}=\max _{\lambda \delta}\left\{\beta_{1, m}^{i}, \beta_{2}^{i}\right\}
$$

st. 


$$
\begin{cases}\vec{D}_{(I)}^{Y}\left(\tilde{y}_{m}+\beta_{1} g_{\tilde{y}_{m}}, x_{n}, \tilde{q}_{k}, c_{d}, w_{a}\right): & \beta_{1, m}^{i} g_{\tilde{y}_{m}}^{i}+\tilde{y}_{m}{ }^{i} \leq \sum_{i} \lambda^{i} \tilde{y}_{m}{ }^{i}, m=1, \ldots, M, \lambda \in \mathbb{R}_{+}^{I} \\ & x_{n}{ }^{i} \geq \sum_{i} \lambda^{i} x_{n}{ }^{i}, n=1, \ldots, N \\ & c_{d}{ }^{i} \geq \sum_{i} \lambda^{i} c_{d}{ }^{i} \\ \tilde{q}_{k}{ }^{i} \geq \sum_{i} \lambda^{i} \tilde{q}_{k}{ }^{i}, k=1, \ldots, K \\ w_{a}{ }^{i} \geq \sum_{i} \lambda^{i} w_{a}{ }^{i}, a=1, \ldots, A \\ \vec{D}_{(I)}^{S c}\left(S c+\beta_{2} g_{S c}, x_{n}, \tilde{z}_{k}, c_{d}, w_{a}\right): \quad \beta_{2}^{i} g_{S c}^{i}+S c^{i} \leq \sum_{i} \delta^{i} S c^{i}, \delta \in \mathbb{R}_{+}^{I} \\ x_{n}{ }^{i} \geq \sum_{i} \delta^{i} x_{n}{ }^{i} n=1, \ldots, N \\ c_{d}{ }^{i}=\sum_{i} \delta^{i} c_{d}{ }^{i} \\ \tilde{z}_{k}{ }^{i}=\sum_{i} \delta^{i} \tilde{z}_{k}{ }^{i}, k=1, \ldots, K \\ w_{a}{ }^{i} \geq \sum_{i} \delta^{i} w_{a}{ }^{i}, a=1, \ldots, A\end{cases}
$$

2 Notice that $\vec{D}_{(I)}\left(x_{n}, \tilde{q}_{k}, c_{d}, w_{a}, \tilde{z}_{k}, \tilde{y}_{m}, S c, g_{\tilde{y}_{m}}, g_{S c}\right)$ represents the production technology which is 3 an interaction between the desirable output technology in Eq. 7 (a) and the social output technology 4 in Eq. 7(b). The vector $\beta=\left(\beta_{1, m}, \beta_{2}\right)$ is non-negative, and represents the maximum feasible expansion of non-random desirable outputs $\left(\tilde{y}_{m}\right)$ and social output $(S c)$ to reach the frontier of the outputs set

$7 \quad\left(\tilde{y}_{m}+\beta_{1, m} g_{\tilde{y}_{m}}, S c+\beta_{2} g_{S c}\right) \in T$ where $\beta=\vec{D}_{(I)}\left(x_{n}, \tilde{q}_{k}, c_{d}, w_{a}, \tilde{z}_{k}, \tilde{y}_{m}, S c, g_{\tilde{y}_{m}}, g_{S c}\right)$. The objective function in Eq. 7 (a) is to maximize the production of desirable output $\left(\tilde{y}_{m}\right)$

9 with the minimum use of inputs. The first constraint of the Eq. 7 (a) ensures that the production set is 10 feasible. In the second restriction, we are assuming that an increase in productive inputs which 11 includes crop land $\left(x_{1}\right)$, capital $\left(x_{2}\right)$, energy $\left(x_{3}\right)$ and work $\left(x_{4}\right)$, will increase the production of 12 agricultural crops. In the third and the fourth constraint, we are assuming that chemicals application $13\left(c_{d}\right)$ and the state-contingent fertilizer that remains on the crop $\left(\tilde{q}_{k}\right)$ has a positive impact on the 
1 quantity of crop produced. In the last restriction in Eq. 7 (a), we specifically assume that improved

2 working conditions of the farmers $\left(w_{a}\right)$ helps increasing the production of agricultural desirable 3 outputs.

In the social output technology model Eq. 7 (b), the objective function is to maximize the

5 production of social outputs $(S c)$ while holding all other inputs constant. The first restriction implies

6 feasibility of contraction of social outputs. The second constrain implies that the use of conventional

7 inputs $\left(x_{n}\right)$ such as labor, will increases rural employment and thus maintains viability of rural areas

8 and, consequently, enhancing the social sustainability performance of agricultural holdings. In

9 contract to the first model Eq. (7a), in the model Eq. (7b), we impose equalities for the third and the

10 fourth constraint, these two equalities implies that an increase in the use chemicals application $\left(c_{d}\right)$

11 and the state-contingent nitrogen runoff $\left(\tilde{z}_{k}\right)$ will decrease the agricultural social benefits ${ }^{7}$. The fifth

12 constraint assumes that good working conditions tend to improve farmer's well-being and thus ease

13 the generation of social benefits.

14 Our empirical analysis identifies the efficient farms as the ones for which $\beta$ is equal to zero.

15 These efficient farms have no unique shadow prices, while inefficient farms with $\beta>0$ are located

16 inside the best-practice frontier with a differentiable distance function which provides them a single

17 shadow price (Chambers et al., 2014; Chambers and Färe, 2008).

\subsection{Shadow price calculation}

19 Shadow pricing estimation is widely used in efficiency and productivity literature to measure the

20 internal value of undesirables outputs generated from production activities (Fare et al., 1993; Leleu,

21 2013; Wang et al., 2016). In this study, we use the concept of DDF to estimate shadow prices of social

22 outcomes generated from agricultural activities.

\footnotetext{
${ }^{7}$ This assumption lies behind the fact that the use of agro-chemical inputs such as pesticides and fertilizers has increased agricultural production and productivity. However, environmental and health hazards from such use have increased too (Wilson and Tisdell, 2001).
} 

which is the most commonly used approach when the purpose of the study is to estimate distances. The second one is the dual multiplier form which is a "mirror image" of the envelopment form

$4 \vec{D}_{(I)}\left(x_{n}, \tilde{q}_{k}, c_{d}, w_{a}, \tilde{z}_{k}, \tilde{y}_{m}, S c, g_{\tilde{y}_{m}}, g_{S c}\right)$ that enables the estimation of inputs and outputs shadow 5 prices. Following previous studies (Chambers et al., 2014; Serra and Poli, 2015) the multiplier 6 formulation can be derived as follows:

$7 \quad \vec{E}_{(I)}\left(x_{n}, \tilde{q}_{k}, c_{d}, w_{a}, \tilde{z}_{k}, \tilde{y}_{m}, S c, g_{\tilde{y}_{m}}, g_{S c}\right)$

$$
=\operatorname{Max}\left\{\theta_{m s} y_{m s}^{i}+\mu S c^{i}-\left(\omega_{1}-\omega_{2}\right) c_{d}^{i}-\psi_{k s} z_{k s}^{i}-\eta_{k s} q_{k s}^{i}-\xi_{n} x_{n}^{i}-\sigma_{a} w_{a}^{i}\right\}
$$

st.

$\theta_{m s} y_{m s}^{i}+\mu S c^{i} \geq 1$

$$
\begin{aligned}
\sum_{m} \sum_{s} \theta_{m s} y_{m s}^{i} & +\sum_{k} \mu S c^{i}-\sum_{d}-\left(\omega_{1}-\omega_{2}\right) c_{d}^{i}-\sum_{k} \sum_{s} \psi_{k s} z_{k s}^{i}-\sum_{k} \sum_{s} \eta_{k s} q_{k s}^{i}-\sum_{n} \xi_{n} x_{n}^{i} \\
& -\sum_{a} \sigma_{a} w_{a}^{i} \leq 0 \quad \text { for all } i, i=1, \ldots, I
\end{aligned}
$$

where $\left(\omega_{1}-\omega_{2}\right), \psi_{k s}, \eta_{k s}, \xi_{n}$ and $\sigma_{a}$ denote the internal values associated with $c_{d}$ (chemicals application), $\tilde{z}_{k}$ (nitrogen runoff), $\tilde{q}_{k}$ (nitrogen removal that is absorbed by the plant), $x_{n}$ (traditional inputs that include land, capital, labor and the cost of energy) and $w_{a}$ (working conditions), respectively. $\theta_{m s}$ and $\mu$ refer to the shadow values of random desirable outputs and social output, respectively.

The shadow prices $\left(\omega_{1}-\omega_{2}\right), \psi_{k s}, \eta_{k s}, \xi_{n}, \sigma_{a}, \theta_{m s}$ and $\mu$ are derived as the solution to the multiplier problem in Eq. (8). These multiplier prices are reported for each unit. They are not market prices but they are assigned as the value of the contribution of each output and input to production efficiency, which can be very useful when dealing with netputs with non- monetary valuation. The smoothly differentiable representation of the technology in Eq. (7) allows to derive a 23 single shadow price for inefficient farms that are inside the frontier. However, as pointed out by 
1 Chambers et al. (2014), in experimental studies within the field of environmental and resource

2 economics, the resulting frontier of the enveloped inputs and output data is not smooth and contains kinks. These kinks are the extreme efficient units which instead of having unique shadow prices, are characterized by an internal value which is enclosed between a maximum and a minimum bound. In this article, we draw on the work of Chambers and Färe, (2008) that propose directional derivative concept to estimate shadow prices for the units that are operating at the kinks of the best practice frontier.

8

Based on the DDF representation of the production technology in Eq. (7), Chambers and Färe (2008) define the lower and upper bounds of the shadow prices in terms of willingness to pay (WTP) and willingness to accept (WTA), respectively, as follows:

$$
\left[\operatorname{Min}\left\{\partial^{y_{m s} \vec{D}_{(I)}}(\cdot)\right\}, \operatorname{Max}\left\{\partial^{y_{m s} \vec{D}_{(I)}}(\cdot)\right\}\right]
$$

where $\partial^{y_{m s}} \vec{D}_{(I)}(\cdot)$ is the directional derivative of the envelopment form $\vec{D}_{(I)}$ with respect to the state contingent outputs $\tilde{y}_{m}$ given the directional vector $g_{\tilde{y}_{m}}$. The upper and lower bounds, within which the shadow prices are situated, are generated when the distance function cannot be smoothly differentiated. However, for a smooth technology, upper and lower bounds correspond to the same value.

As shown by Chambers et al. (2014), shadow price estimation for efficient units requires deriving directional derivatives from the multiplier form in Eq. (8) as follows:

$$
\left[\operatorname{Min}\left\{\partial^{y_{m s} \vec{E}_{(I)}}(\cdot)\right\}, \operatorname{Max}\left\{\partial^{y_{m s}} E_{(I)}(\cdot)\right\}\right]
$$

Where $\partial^{y_{m s}} \vec{E}_{(I)}(\cdot)$ represents the directional derivative of the multiplier version in Eq. (8). For units with a smooth technology, shadow prices are derived as the optimal solutions to the multiplier problem in Eq. (8). However, as mentioned above, the technology is not differentiable for efficient units, which leads to multiple solutions for the multiplier representation in Eq. (8). Therefore, to 
1 derive these optimal solutions, the multiplier form in Eq. (8) is modified by incorporating the

2 following constraint:

$$
\theta_{m s} y_{m s}^{i}+\mu S c^{i}-\left(\omega_{1}-\omega_{2}\right) c_{d}^{i}-\psi_{k s} z_{k s}^{i}-\eta_{k s} q_{k s}^{i}-\xi_{n} x_{n}^{i}-\sigma_{a} w_{a}^{i}=0
$$

4 Thus, the upper (respectively, lower) bound for $\tilde{y}_{m}$ can be calculated by solving the modified version

5 in Eq. (8) which we added the constraint in Eq. (11), with $\tilde{y}_{m}$ as the objective function to be

$7 \vec{E}_{(I)}\left(x_{n}, \tilde{q}_{k}, c_{d}, w_{a}, \tilde{z}_{k}, \tilde{y}_{m}, S c, g_{\tilde{y}_{m}}, g_{S c}\right)=\operatorname{Max}\left\{\theta_{m s}\right\}$

8

st.

$\theta_{m s} y_{m s}^{i}+\mu S c^{i}-\left(\omega_{1}-\omega_{2}\right) c_{d}^{i}-\psi_{k s} z_{k s}^{i}-\eta_{k s} q_{k s}^{i}-\xi_{n} x_{n}^{i}-\sigma_{a} w_{a}^{i}=0$

$\theta_{m s} y_{m s}^{i}+\mu S c^{i} \geq 1$

$$
\begin{aligned}
\sum_{m} \sum_{s} \theta_{m s} y_{m s}^{i} & +\sum_{k} \mu S c^{i}-\sum_{d}-\left(\omega_{1}-\omega_{2}\right) c_{d}^{i}-\sum_{k} \sum_{s} \psi_{k s} z_{k s}^{i}-\sum_{k} \sum_{s} \eta_{k s} q_{k s}^{i}-\sum_{n} \xi_{n} x_{n}^{i} \\
& -\sum_{a} \sigma_{a} w_{a}^{i} \leq 0 \quad \text { for all } i, i=1, \ldots, I
\end{aligned}
$$

The solution derived from solving Eq. (12) corresponds to the upper shadow price bound for each of the efficient farms for its random output. The lower price bound is derived by minimizing the objective function in Eq. (12). Similarly, the upper and lower price bounds of the social ${ }^{8}$ output are obtained by redefining the objective function in Eq. (12) as follows:

$$
\begin{aligned}
& \vec{E}_{(I)}\left(x_{n}, \tilde{q}_{k}, c_{d}, w_{a}, \tilde{z}_{k}, \tilde{y}_{m}, S c, g_{\tilde{y}_{m}}, g_{S c}\right)=\operatorname{Max}\{\mu\} \\
& \vec{E}_{(I)}\left(x_{n}, \tilde{q}_{k}, c_{d}, w_{a}, \tilde{z}_{k}, \tilde{y}_{m}, S c, g_{\tilde{y}_{m}} g_{S c}\right)=\operatorname{Min}\{\mu\}
\end{aligned}
$$

\footnotetext{
${ }^{8}$ State-contingent social outputs' shadow prices are computed as the solution of the multiplier form based on state-contingent output variables
} 
2 Our research uses cross sectional, farm-level data collected from a sample of 180 Catalan arable crop

3 farms (Figure 1) specialized in the production of cereals, oilseeds and protein (COP) crops.

4 Implementing an empirical approach within state contingent technologies requires data on ex-ante

5 random variables (Chambers and Quiggin, 2000), and we rely on the work of Chambers et al., (2015)

6 to implement the data gathering process. The survey to farmers was conducted in two stages. The

7 first survey, before the growing season (2015), aimed at collecting information on planned input use

8 and ex-ante outputs, allowing us to empirically represent the stochastic production technology in

9 terms of a state contingent approach. The second survey (2016) gathered ex-post outputs data. The

10 state-contingent approach is based on the theory that production under risk can be differentiated

11 according to the state of nature in which it is realized. Three alternative states of nature are used to

12 collect data on ex-ante outputs, in bad, normal and ideal growing conditions $y=\left(y_{1}, y_{2}, y_{3}\right)$. For

13 more details see Chambers et al. (2015) and Serra et al. (2014).

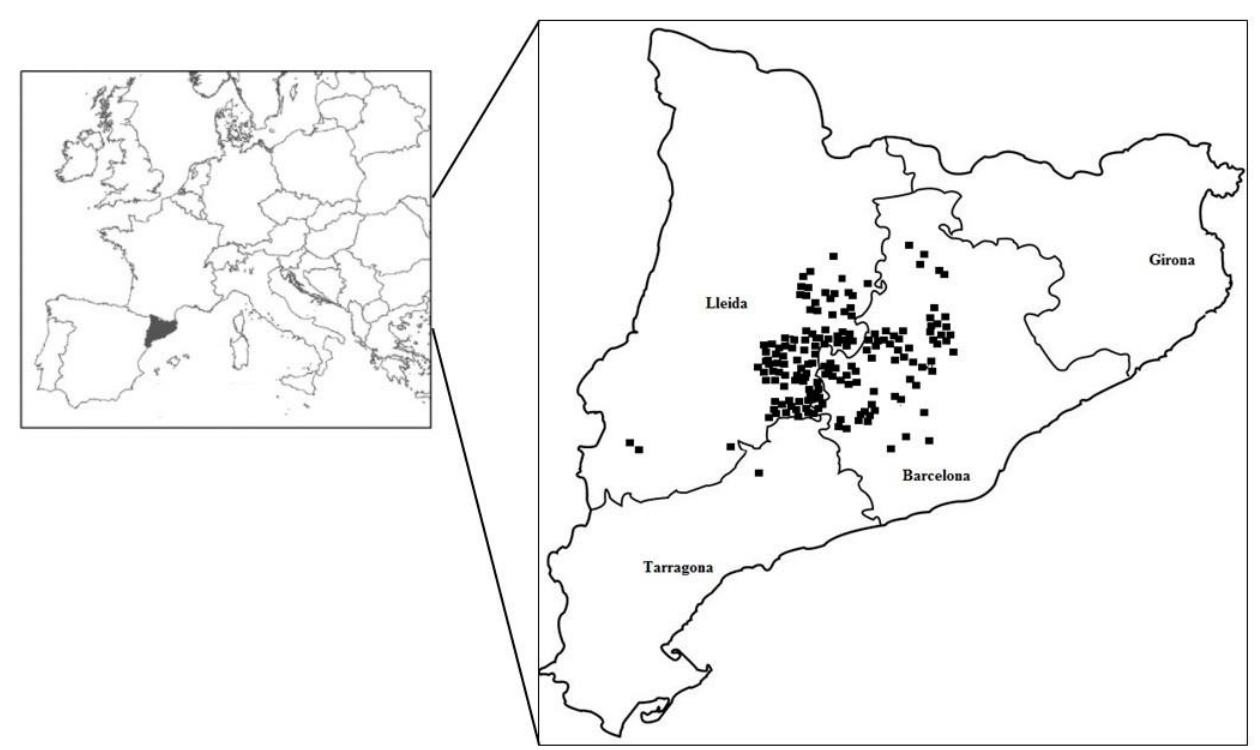

14

15 Figure 1. Distribution of our sample of 180 arable crop farms Social across the region of Catalonia 16 
The main characteristics of the sample are presented in Table 4. Two desirable outputs are considered: a state-contingent crop output $\left(\tilde{y}_{n}\right)$ that fluctuates on average from more than 33 thousand Euros in the bad state to more than 71 thousand Euros in the ideal state of nature. The desirable social outcomes $(S c)$ associated with agricultural activities are considered as another desirable output. To derive a quantitative measure of the social output, farmers were asked to provide their appreciation on a set of items. A four-point Likert scale was used to this end. The multi-items statement are presented in table 4. Principal component analysis (PCA) was performed using the eight social outcomes items. Two orthogonal components, with an eigenvalue greater than 1 that accounts more than $65 \%{ }^{9}$ of the information, were selected. PCAs may show negative values, which are not possible to use in DEA approach. Therefore, all values were increased by the most negative value in the vector plus one, thus ensuring that our data are strictly positive. For convenience purposes when estimating shadow prices of the social output, the two PCA components were summed, showing an average score of 7.83 where an increasing value denotes higher level of social outcomes as rated by farmers.

As explained above, nine inputs are used in our analysis. These include crop land $\left(x_{1}\right.$ in hectares), value of capital ( $x_{2}$ in Euros), energy cost ( $x_{3}$ in Euros), paid and unpaid labor together ( $x_{4}$ in hours), and crop-specific inputs: quantity of chemicals applied (c) in liters, state-contingent fertilizers absorbed by the crops ( $\tilde{q}_{n}$ in kilos) and state-contingent nitrogen balance ( $\tilde{z}_{n}$ in kilos). On average, our sample farms cultivate 80.62 ha, have a capital value of 157 thousand Euros, devote slightly more than 939 labor hours per year to the farm and spend around 4,8 thousand Euros on energy.

While Spain accounts for almost $20 \%$ of the EU-28 consumption in 2014, our sample farms apply on average 103 liters of chemicals (pesticides, herbicide, insecticide), which correspond to a rate of 1.28 liters per hectare. Schreinemachers and Tipraqsa (2012) report a value around $1.7 \mathrm{~kg} / \mathrm{ha}$ for Spain, which implies that our sample farms are below the national average. By assuming that only

\footnotetext{
${ }^{9}$ Hair et al. (2010) point out that in social sciences, low percentages of variance criterion are not uncommon. Considering a solution that captures 60 percent (even less) of the total variance can be considered as acceptable.
} 
1 the absorbed fraction by the plant has an effect on the final production, our representation treats the

2 nitrogen absorption as a state-contingent. The reason for this is that growing conditions related to the

3 environment might play a major role in determining which elements of the applied input will be fixed

4 on the plant and which elements are lost to the environment in the atmosphere and water. Thus, we

5 estimated three possible nitrogen removal quantities per farm $\left(q_{1}, q_{2}, q_{3}\right)$ (see Serra et al. (2014) for

6 more details), that fluctuate from 3.7 thousand to 7.4 thousand kilos in bad and ideal crop growing

7 conditions. By computing the difference between nitrogen applied and nitrogen removed, three

8 possible nitrogen balances (one for each state of nature) were generated $\left(z_{1}, z_{2}, z_{3}\right)$. The nitrogen

9 balance follows a decreasing trend while growing conditions improve as the absorbed nitrogen is

10 higher under good crop growing conditions. Finally, our inputs includes a measure of farmers'

11 working conditions ${ }^{10}\left(w_{a}\right)$. Farmers were asked to rate, based on a four-point Likert scale, 17 items

12 reflecting different dimensions of working conditions (workload, difficulty of the work, creativity,

13 skills development, freedom in decision making, flexibility of schedules, work motivation).

\footnotetext{
${ }^{10}$ A principal component analysis (PCA) procedure is applied on the working conditions vector in order to reduce the number of inputs and improve the discrimination ability of the DEA model.
} 
Table 4. Descriptive statistics

\begin{tabular}{|c|c|c|c|c|c|c|c|}
\hline & $\begin{array}{c}\text { Technology } \\
\mathrm{T}^{\mathrm{Y}}\end{array}$ & $\begin{array}{c}\text { Technology } \\
\mathrm{T}^{\mathrm{Sc}}\end{array}$ & Variable description & Unit & Notation & Mean & Std. Dev. \\
\hline \multirow[t]{13}{*}{ Inputs } & $\checkmark$ & $\checkmark$ & Land & Hectares & $\overline{x_{1}}$ & 80.65 & 73.60 \\
\hline & $\checkmark$ & $\checkmark$ & Capital & Euros & $x_{2}$ & 157836.59 & 169036.44 \\
\hline & $\checkmark$ & $\checkmark$ & Energy & Euros & $x_{3}$ & 4851.58 & 5258.15 \\
\hline & $\checkmark$ & $\checkmark$ & Work & Hours & $x_{4}$ & 939.70 & 3577.22 \\
\hline & $\checkmark$ & $\checkmark$ & Chemicals active ingredients applied & Liters & $c_{d}$ & 103.34 & 149.65 \\
\hline & & & Nitrogen application through fertilizers and seeds ${ }^{11}$ & Kilograms & $r_{k}$ & 10054.54 & 11227.39 \\
\hline & $\checkmark$ & $\checkmark$ & Working conditions & - & $w_{a}$ & 4.64 & 0.41 \\
\hline & $\checkmark$ & & Nitrogen absorbed by crops under bad conditions & Kilograms & $q_{1}$ & 3629.63 & 3631.72 \\
\hline & $\checkmark$ & & Nitrogen absorbed by crops under normal conditions & Kilograms & $q_{2}$ & 5317.00 & 5210.91 \\
\hline & $\checkmark$ & & Nitrogen absorbed by crops under ideal conditions & Kilograms & $q_{3}$ & 7297.47 & 7599.26 \\
\hline & & $\checkmark$ & Nitrogen balance under bad conditions & Kilograms & $z_{1}$ & 6539.73 & 8676.82 \\
\hline & & $\checkmark$ & Nitrogen balance under normal conditions & Kilograms & $z_{2}$ & 5083.61 & 7598.51 \\
\hline & & $\checkmark$ & Nitrogen balance under ideal conditions & Kilograms & $z_{3}$ & 3844.67 & 6397.63 \\
\hline \multirow[t]{4}{*}{ Outputs } & $\checkmark$ & & Crop output value under bad conditions & Euros & $y_{1}$ & 33024.49 & 34050.12 \\
\hline & $\checkmark$ & & Crop output value under normal conditions & Euros & $y_{2}$ & 52114.47 & 50695.80 \\
\hline & $\checkmark$ & & Crop output value under ideal conditions & Euros & $y_{3}$ & 71570.62 & 72414.69 \\
\hline & & $\checkmark$ & Social output & - & $S C_{g}$ & 7.83 & 1.41 \\
\hline
\end{tabular}

${ }^{11}$ Nitrogen application $r_{k}$ has not been used directly in this analysis, since it was used to implement the materials balance principles, as the total amount of applied nitrogen represents the part that has been absorbed by the crops, plus the part that remains in the environment (runoff), according to $r_{k}=\tilde{q}_{k s}+\tilde{z}_{k s}$. 
Table 5 shows the averages and the frequency distribution of the overall efficiency scores

3 calculated with DDF for each state of nature. The efficiency ratings for best performing farms that

4 are derived for each state in this evaluation would only represent the set of units considered in the

5 analysis. Our findings show relatively high performance of the sample farms, indicating strong

6 efficiency in the usage of inputs, which is compatible with previous literature findings (Godoy-Durán

7 et al., 2017). A small difference is observed across the different states of nature, from $85 \%$ for the

8 bad state of nature to $88 \%$ for the normal and ideal crop growing conditions. This suggests that most

9 of the farms are operating close to the best-practice frontier, with 21 farms observed as fully efficient

10 (i.e. on the best-practice frontier) under bad conditions, 25 under normal conditions, and 30 under

11 ideal growing conditions. Figure 2 summarizes the scores as a graphical representation in the form of

12 histograms and nonparametric kernel density functions. Strong negative skewness for the three states

13 of nature suggests that many farms are located near to the full efficient level of one. However, a non-

14 unimodal distribution can be observed for the three panels (confirmed by Hartigans' dip test for

15 unimodality) with many farms having an efficiency score around 0.85 and 0.95 .

16

17 Table 5. Distribution of farms depending on their DEA efficiency scores

\begin{tabular}{lccc}
\hline & & Number of farms & \\
\hline & $\begin{array}{c}\text { Calculation } \\
\text { under bad } \\
\text { state of nature }\end{array}$ & $\begin{array}{c}\text { Calculation } \\
\text { under normal } \\
\text { state of nature }\end{array}$ & $\begin{array}{c}\text { Calculation } \\
\text { under ideal } \\
\text { state of nature }\end{array}$ \\
\hline $0<\epsilon<10$ & 0 & 0 & 0 \\
$10<\epsilon<20$ & 0 & 0 & 0 \\
$20<\epsilon<30$ & 0 & 0 & 0 \\
$30<\epsilon<40$ & 0 & 0 & 0 \\
$40<\epsilon<50$ & 0 & 0 & 0 \\
$50<\epsilon<60$ & 2 & 0 & 0 \\
$60<\epsilon<70$ & 11 & 3 & 2 \\
$70<\epsilon<80$ & 46 & 33 & 39 \\
$80<\epsilon<90$ & 54 & 56 & 53 \\
$90<\epsilon<100$ & 46 & 63 & 30 \\
$\epsilon=100$ & 21 & 25 & 88,27 \\
Average Score $(\%)$ & & & \\
\hline
\end{tabular}




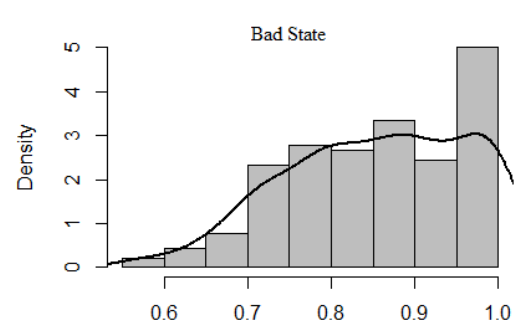

1

2

\section{.}

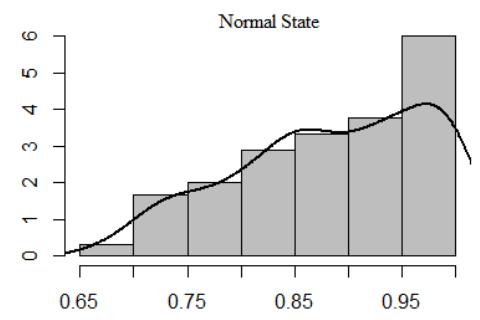

Efficiency values

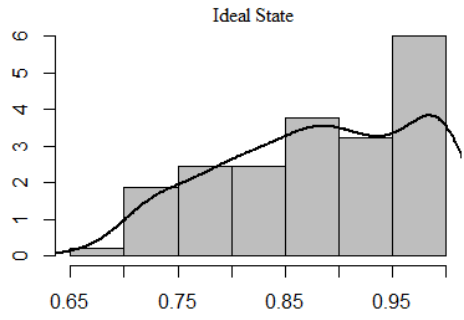

95

unique for the inefficient farm and provides a measure of the shadow values that each farm allocates

to its netputs bundle. For the efficient farms, we follow Chambers and Färe (2008) approach to compute the multiple shadow prices solutions. Table 6 presents average shadow prices of social outcome and desirable state-contingent outputs for the efficient and non-efficient farms. The calculated average shadow prices of desirable state-contingent outputs for efficient and inefficient farms are positive, implying that the production of desirable outputs contributes in a positive way in adding value for the farms. This finding supports the positive relationship between social issues and production performance (Chen and Holden, 2018; Chopin et al., 2016; Sáez-Martínez et al., 2016; Tang, 2018) and is in line with previous research (Petit et al., 2018)

For the efficient and non-efficient farms, results show a downward trend of the desirable outputs' shadow prices as crop-growing conditions improve. In other words, producing an additional unit of good output will eventually cost less in the ideal growing conditions. For the efficient farms, our results suggest also a decreasing range of shadow prices with the improvement in crop growth conditions. A lower WTA in the ideal state of nature than in the other states of nature indicates that farmers are willing to engage in producing more units of the good output as the conditions are improving. This result is not surprising and indicates that the farm's marginal costs are lower when nature choses the ideal state. Our findings are consistent with previous studies reporting that upper and lower bounds of desirable outputs' shadow prices are lower in the ideal state of nature than in the other states of nature (Chambers et al., 2014). 
Table 6. Descriptive statistics of shadow prices of desirable state-contingent output and social outputs for efficient and inefficient farms

\begin{tabular}{|c|c|c|c|c|c|c|c|c|c|c|}
\hline & & \multicolumn{3}{|c|}{ Inefficient farms } & \multicolumn{6}{|c|}{ Efficient farms } \\
\hline & \multirow[b]{2}{*}{$\begin{array}{c}\text { State of } \\
\text { nature }\end{array}$} & \multirow[b]{2}{*}{ Average } & \multirow[b]{2}{*}{ Min } & \multirow[b]{2}{*}{ Max } & \multicolumn{3}{|c|}{ WTP } & \multicolumn{3}{|c|}{ WTA } \\
\hline & & & & & Average & Min & Max & Average & Min & Max \\
\hline \multirow{3}{*}{$\begin{array}{l}\text { Desirable } \\
\text { outputs }\end{array}$} & $\mathrm{Bad}$ & $3,78 \mathrm{E}-05$ & $-5.23 \mathrm{E}-07$ & $3.26 \mathrm{E}-04$ & $6.53 \mathrm{E}-07$ & 0,00 & $1.30 \mathrm{E}-05$ & $5.12 \mathrm{E}-05$ & $3.81 \mathrm{E}-06$ & $1.82 \mathrm{E}-04$ \\
\hline & Normal & $2,53 \mathrm{E}-05$ & 0.00 & $1.47 \mathrm{E}-04$ & $5.90 \mathrm{E}-07$ & 0,00 & $8.75 \mathrm{E}-06$ & 2.94E-05 & $2.58 \mathrm{E}-06$ & $1.10 \mathrm{E}-04$ \\
\hline & Ideal & $1,70 \mathrm{E}-05$ & 0.00 & 8.13E-05 & $5.02 \mathrm{E}-07$ & 0,00 & 7.63E-06 & $1.98 \mathrm{E}-05$ & $1.74 \mathrm{E}-06$ & $6.77 \mathrm{E}-05$ \\
\hline \multirow{3}{*}{$\begin{array}{l}\text { Social } \\
\text { outputs }\end{array}$} & $\mathrm{Bad}$ & 1219.64 & -34013.77 & 90692.84 & 0.00 & 0,00 & 0.00 & 830.34 & 98.15 & 2884.41 \\
\hline & Normal & 565.79 & 0,00 & 16002.73 & 0.00 & 0,00 & 0.00 & 931.25 & 170.40 & 3432.37 \\
\hline & Ideal & 1092.41 & 0,00 & 45231.84 & 0.00 & 0,00 & 0.00 & 2033.11 & 250.82 & 16232.18 \\
\hline
\end{tabular}



computed using desirable outputs' market price. The most striking fact of these results is the upward trend in the shadow prices as growth conditions improve for the efficient farms. Indeed, the WTP and WTA of social outputs are larger in the 'ideal' state of nature than in the other states of nature. The WTA fluctuates from $830 €$ in the bad state to $2033 €$ in the ideal state, suggesting that when nature goes from poor to favorable growing conditions, the efficient farms require $1203 €$ more to engage in producing one unit of social output. This finding suggests that these efficient farms prefer to allocate more resources in the production of desirable outputs than of social outcomes. Positive social externalities can add value to the farm, however they are costly to generate. Thus, when growing conditions are ideal, these efficient farms choose to focus on private benefits over social and public benefits, conferring more relevance to their own private financial performance. This finding is consistent with previous studies that demonstrated that sustainable practices with high economic cost/benefit ratio are unlikely to be adopted (Hillis et al., 2018; Magon et al., 2018). As shown by Chambers et al. (2014), when the shadow price range of the efficient units encompasses zero, this indicates that the farms are operating at their private optimum level. All our efficient sample farms show a zero social output shadow prices at the lower bound.

\section{Implication for theory and practices on sustainability}

Relying on the main findings of this study, contributions and theoretical implications for different streams of research emerge. First, our article is among the pioneers that investigate the shadow prices of agricultural social outputs from the point of view of academic scientists. Few existing studies have considered the social dimension of firm performance within the production and efficiency literature.

\footnotetext{
${ }^{12}$ As the quantitative measure of social output is derived using PCA, an accurate identification and measurement of one unit of social output is not easy to establish. However, for a better understanding of these results, it would be sufficient to interpret the social output's shadow price as a measure of how much an efficient farm is willing to accept (respectively, pay) for producing (respectively, giving up) one more unit of social output. An identification of these magnitudes across the different states of nature could provide a relevant information when investigating the decision making process at farm-level.
} 
1 This demonstrates the general importance of extending the scope of previous research to quantify social outputs by allowing for the stochastic nature of agricultural production.

With regard to the field of farm management, this study emphasizes the importance of 4 conceptualizing sustainable farming as a multidimensional construct. While many studies still focus 5 exclusively on environmental issues, it rather seems necessary to adopt a more differentiated 6 approach and expand the scope of analysis to the social dimension, which is very important for 7 evaluating overall sustainability (Macombe et al., 2013). Furthermore, this study answers the call of 8 public authorities that suggested a wider perspective in rural areas by targeting economic, 9 environmental, and social objectives (European Commission, 2007, 2001).

10 Incorporating the stochastic nature of production technologies into efficiency and performance 11 analysis can be an important step in understanding the process of managerial decision-making, which 12 can be relevant in developing models and theories of farmers' behavior in managing production 13 uncertainty. Another theoretical implication for research deals with the link between agricultural 14 subsidies and production efficiency. Many studies have considered this association, however, our conceptual approach clearly brings a new perspective in subsidy redistribution scheme.

In addition to the discussed implications on sustainability theory, several practical

17 implications emerge from the results of this paper. The study's results suggest that shadow prices of 18 social outputs are positive, which indicates that engaging in social sustainable agriculture provides 19 benefit for the farm. A policy implication of this finding is that the rural community is able to make 20 social and economic performances complementary rather than substitute. As a result, promoting 21 social sustainability through creating new public services, local development, product responsibility 22 and social cohesion is likely to lead to improved farm financial health.

23 Results also indicate that social outputs' shadow prices are contingent upon the growing 24 conditions. The shadow prices follow an upward trend as crop-growing conditions improve. A key 25 implication of this perspective on sustainability is that optimally-designed regulations and policies supporting socially responsible farming should take into account the state-contingent nature of 
farmers' management. Government subsidies could be a major policy instrument to encourage and

2

promote the production of social benefits, helping to ensure sustainable farming systems. This empirical evidence (Unay-Gailhard and Bojnec, 2016; Varela-Candamio et al., 2018) suggests that subsidies could be used to stimulate public social benefits production, with higher incentives in the ideal state of nature than in the other states of nature.

\section{Concluding remarks}

Maintaining viable rural communities is one of the key strategic aims of the EU's agricultural policy set out in Communication 672/2010 entitled "the CAP towards 2020" (European Commission, 2010).

To fulfill this aim, policy-makers need a better understanding of farmers' decision making process related to social sustainability challenges. In this context, the objective of our article was to provide an empirical evidence that could help support EU agricultural policy-makers. Specifically, it estimated shadow prices of agricultural social outputs, accounting for the stochastic conditions under which production takes place, using a sample of Catalan farms.

Economic performance is an essential requirement for sustainable development and rural viability. In this regard, our results suggest that our sample farms show high performance scores, from $85 \%$ for the bad state of nature to $88 \%$ for the normal and ideal crop growing conditions. This suggests that farm performance is increasing with an improvement in crop growth conditions. Measures of farm performance are needed to identify inefficient and efficient farms. In our article, unique shadow prices were computed for non-efficient farms, while for efficient units, the proposal by Chambers and Färe (2008) was used to derive upper and lower shadow price bounds, these two bounds representing the interval within which the shadow price changes.

Results show that average shadow prices of desirable state-contingent output and social outcomes for efficient and inefficient farms are positive, suggesting that the production of desirable marketable outputs and of non-marketable outputs makes a positive contribution to the farm 
1 production efficiency. Our social outputs' shadow prices estimation makes a meaningful contribution

2 to the literature. First, it represents the first attempt to compute shadow prices of social outcomes

3 while accounting for the stochastic nature of the production technology. Second, our findings suggest

4 that the decision-making process of the efficient farms in dealing with social issues are stochastic and

5 strongly dependent on the growth conditions. This implies that policy-makers should adjust their

6 instruments according to the stochastic environmental conditions. An optimal redistribution of rural

7 development support (which is channeled through the so-called 'second pillar' of the CAP), by

8 increasing the payment with the improvement in crop growth conditions, would likely enhance the

9 effectiveness of greening the CAP.

Our analysis was applied to a sample of Catalan farms, with the DEA method that provide

11 relative measures within a specific sample. It is therefore difficult to generalize our empirical findings

12 to other case studies. However, our conceptual approach clearly contributes to the existing literature

13 on sustainability by providing to academics and policy-makers an innovative approach that allows

14 the virtual quantification of the social dimension of sustainable agriculture. Such approach could be applied to various case studies, in particular where the uncertainty of growing conditions is high.

17 clearly identify a broader range of social sustainability indicators to obtain more detailed information on this issue, which would allow for more accurate assessment of the social dimension of sustainable farming performance. Further extensions of this work could also consider other techniques. For example, a meta-frontier analysis in a DEA framework (O'Donnell et al., 2008) would allow a 21 comparison of different types of farms operating in different regions or under different technologies, 22 in order to identify which type's technology is the more productive in terms of social outputs. 23 Assessing social sustainability performance by comparing cereal farms versus non-cereal farms 24 would be very relevant. Another interesting area for future research would involve the consideration 25 of regional differences based on environmental issues, as nitrate pollution strongly affects the 26 Mediterranean coast (European Commission, 1999), it would be interesting to investigate how 
1 environmental sustainability practices affect the social dimension, by assessing the social outputs'

2 shadow prices for farms operating in nitrate vulnerable zones compared to farms that operate in less

3 vulnerable areas. Finally, another interesting area for future research would be to compare results

4 obtained with our nonparametric approach with those estimated from a parametric approach where

5 the production function has to be fully specified.

\section{Acknowledgements:}

7 The author gratefully acknowledges financial support from Instituto Nacional de Investigaciones

8 Agrícolas (INIA) from Spain and the European Regional Development Fund (ERDF), Plan Nacional

9 de Investigación Científica, Desarrollo e Innovación Tecnológica (I+D+i), Project Reference Number

10 RTA2012-00002-00-00.

11 The author is very grateful to Laure Latruffe for the invaluable help.

12

13

14

15

16

17

18

19

20

21

22

23

24

25

26

27 


\section{References}

Ağan, Y., Kuzey, C., Acar, M.F., Açıkgöz, A., 2016. The relationships between corporate social responsibility, environmental supplier development, and firm performance. J. Clean. Prod. 112, 1872-1881. doi:10.1016/J.JCLEPRO.2014.08.090

Aiken, D.V., Pasurka, C.A., 2003. Adjusting the measurement of US manufacturing productivity for air pollution emissions control. Resour. Energy Econ. 25, 329-351. doi:10.1016/S09287655(03)00042-3

Allen, P., Van Dusen, D., Lundy, J., Gliessman, S., 1991. Integrating social, environmental, and economic issues in sustainable agriculture. Am. J. Altern. Agric. 6, 34. doi:10.1017/S0889189300003787

Arrow, K.J., Debreu, G., 1954. Existence of an Equilibrium for a Competitive Economy. Econometrica 22, 265. doi:10.2307/1907353

Ayres, R.U., Kneese, A. V., 1969. Production, Consumption, and Externalities. Am. Econ. Rev. doi:10.2307/1808958

Badri Ahmadi, H., Kusi-Sarpong, S., Rezaei, J., 2017. Assessing the social sustainability of supply chains using Best Worst Method. Resour. Conserv. Recycl. 126, 99-106. doi:10.1016/J.RESCONREC.2017.07.020

Barr, S., Shaw, G., Coles, T., 2011. Times for (Un)sustainability? Challenges and opportunities for developing behaviour change policy. A case-study of consumers at home and away. Glob. Environ. Chang. 21, 1234-1244. doi:10.1016/J.GLOENVCHA.2011.07.011

Battini, F., Agostini, A., Tabaglio, V., Amaducci, S., 2016. Environmental impacts of different dairy farming systems in the Po Valley. J. Clean. Prod. 112, 91-102. doi:10.1016/J.JCLEPRO.2015.09.062

Boström, M., 2012. The problematic social dimension of sustainable development: the case of the Forest Stewardship Council. Int. J. Sustain. Dev. World Ecol. 19, 3-15. doi:10.1080/13504509.2011.582891

Boström, M., 2010. The challenges in achieving the "social" dimension of sustainable development: the case of the Forest Stewardship Council.

Cecchini, L., Venanzi, S., Pierri, A., Chiorri, M., 2018. Environmental efficiency analysis and 
estimation of $\mathrm{CO} 2$ abatement costs in dairy cattle farms in Umbria (Italy): A SBM-DEA model with undesirable output. J. Clean. Prod. 197, 895-907.

doi:10.1016/J.JCLEPRO.2018.06.165

Chambers, R.G., Chung, Y., Färe, R., 1998. Profit, Directional Distance Functions, and Nerlovian Efficiency. J. Optim. Theory Appl. 98, 351-364. doi:10.1023/A:1022637501082

Chambers, R.G., Chung, Y., Färe, R., 1996. Benefit and distance functions. J. Econ. Theory 70, 407-419.

Chambers, R.G., Färe, R., 2008. A “calculus” for data envelopment analysis. J. Product. Anal. 30, $169-175$.

Chambers, R.G., Quiggin, J., 2000. Uncertainty, production, choice, and agency: the statecontingent approach. Cambridge University Press.

Chambers, R.G., Quiggin, J., 1998. Cost functions and duality for stochastic technologies. Am. J. Agric. Econ. 80, 288-295.

Chambers, R.G., Serra, T., 2016. The social dimension of firm performance: a data envelopment approach. Empir. Econ. 1-18.

Chambers, R.G., Serra, T., Oude Lansink, A., 2014. On the pricing of undesirable state-contingent outputs. Eur. Rev. Agric. Econ. 41, 485-509. doi:10.1093/erae/jbu018

Chambers, R.G., Serra, T., Stefanou, S.E., 2015. Using ex ante output elicitation to model statecontingent technologies. J. Product. Anal. 43, 75-83.

Chang, R.-D., Zuo, J., Zhao, Z.-Y., Soebarto, V., Lu, Y., Zillante, G., Gan, X.-L., 2018. Sustainability attitude and performance of construction enterprises: A China study. J. Clean. Prod. 172, 1440-1451. doi:10.1016/J.JCLEPRO.2017.10.277

Chavas, J.-P., 2008. A Cost Approach to Economic Analysis Under State-Contingent Production Uncertainty. Am. J. Agric. Econ. 90, 435-446. doi:10.1111/j.1467-8276.2007.01118.x

Chen, P.-H., Ong, C.-F., Hsu, S.-C., 2016. Understanding the relationships between environmental management practices and financial performances of multinational construction firms. J. Clean. Prod. 139, 750-760. doi:10.1016/J.JCLEPRO.2016.08.109

Chen, W., Holden, N.M., 2018. Tiered life cycle sustainability assessment applied to a grazing dairy farm. J. Clean. Prod. 172, 1169-1179. doi:10.1016/J.JCLEPRO.2017.10.264

Chen, Y., Cook, W.D., Du, J., Hu, H., Zhu, J., 2015. Bounded and discrete data and Likert scales 
in data envelopment analysis: Application to regional energy efficiency in China. Ann. Oper. Res. 1-20.

Chopin, P., Tirolien, J., Blazy, J.-M., 2016. Ex-ante sustainability assessment of cleaner banana production systems. J. Clean. Prod. 139, 15-24. doi:10.1016/J.JCLEPRO.2016.08.036

Chung, L., Lo, C.W.-H., Li, P.H.Y., 2016. The interaction effects of institutional constraints on managerial intentions and sustainable performance. Int. J. Prod. Econ. 181, 374-383. doi:10.1016/J.IJPE.2016.01.001

Coelli, T., Lauwers, L., Van Huylenbroeck, G., 2007. Environmental efficiency measurement and the materials balance condition. J. Product. Anal. 28, 3-12.

Cooper, T., Hart, K., Baldock, D., 2009. The provision of public goods through agriculture in the European Union, report prepared for DG Agriculture and Rural Development,. Institute for European Environmental Policy.

Cooper, W.W., Seiford, L.M., Zhu, J., 2011. Handbook on Data Envelopment Analysis. Springer Science \& Business Media. doi:10.1007/978-1-4419-6151-8

Cuthill, M., 2010. Strengthening the "social"in sustainable development: Developing a conceptual framework for social sustainability in a rapid urban growth region in Australia. Sustain. Dev. $18,362-373$.

Dakpo, K.H., Jeanneaux, P., Latruffe, L., 2017. Greenhouse gas emissions and efficiency in French sheep meat farming: A non-parametric framework of pollution-adjusted technologies. Eur. Rev. Agric. Econ. 44, 33-65. doi:10.1093/erae/jbw013

Dempsey, N., Bramley, G., Power, S., Brown, C., 2011. The social dimension of sustainable development: Defining urban social sustainability. Sustain. Dev. 19, 289-300.

Diazabakana, A., Latruffe, L., Bockstaller, C., Desjeux, Y., Finn, J., Kelly, E., Ryan, M., Uthes, S., 2014. A Review of Farm Level Indicators of Sustainability with a Focus on CAP and FADN. Available online ht tp//www3. lei. wur. nl/flint/downloads/reports/FLINT 20.

Dillard, J., Dujon, V., King, M.C., 2008. Understanding the social dimension of sustainability In: Dillard J, Dujon V, King MC, editors. Understanding the social dimension of sustainability. Routledge, London (UK).

Dong, F., Mitchell, P.D., Colquhoun, J., 2015. Measuring farm sustainability using data envelope analysis with principal components: The case of Wisconsin cranberry. J. Environ. Manage. 147, 175-183. doi:10.1016/j.jenvman.2014.08.025 
Edum-Fotwe, F.T., Price, A.D.F., 2009. A social ontology for appraising sustainability of construction projects and developments. Int. J. Proj. Manag. 27, 313-322. doi:10.1016/J.IJPROMAN.2008.04.003

European Commission, 2013. Overview of CAP Reform 2014-2020.

European Commission, 2010. The CAP towards 2020: Meeting the food, natural resources and territorial challenges of the future. Brussels.

European Commission, 2007. The importance and contribution of the agri-food sector to the sustainable development of rural areas. Brussels.

European Commission, 2001. A Framework for Indicators for the Economic and Social Dimensions of Sustainable Agriculture and Rural Development. Brussels.

European Commission, 1999. Verification of the Vulnerable Zones Identified Under the Nitrates Directive and Sensitive Areas Identified Under the Urban Waste Water Treatment Directive. Brussels.

Färe, R., Grosskopf, S., 2000. Theory and Application of Directional Distance Functions. J. Product. Anal. 13, 93-103. doi:10.1023/A:1007844628920

Fare, R., Grosskopf, S., Lovell, C.A.K., Yaisawarng, S., 1993. Derivation of Shadow Prices for Undesirable Outputs: A Distance Function Approach. Rev. Econ. Stat. 75, 374. doi: $10.2307 / 2109448$

Färe, R., Grosskopf, S., Noh, D.-W., Weber, W., 2005a. Characteristics of a polluting technology: theory and practice. J. Econom. 126, 469-492.

Färe, R., Grosskopf, S., Noh, D.-W., Weber, W., 2005b. Characteristics of a polluting technology: theory and practice. J. Econom. 126, 469-492. doi:10.1016/J.JECONOM.2004.05.010

Fathollahi, H., Mousavi-Avval, S.H., Akram, A., Rafiee, S., 2018. Comparative energy, economic and environmental analyses of forage production systems for dairy farming. J. Clean. Prod. 182, 852-862. doi:10.1016/J.JCLEPRO.2018.02.073

Ferri, L.M., Pedrini, M., 2018. Socially and environmentally responsible purchasing: Comparing the impacts on buying firm's financial performance, competitiveness and risk. J. Clean. Prod. 174, 880-888. doi:10.1016/J.JCLEPRO.2017.11.035

Førsund, F.R., 2009. Good modelling of bad outputs: pollution and multiple-output production. Int. Rev. Environ. Resour. Econ. Forthcom. 
Førsund, F.R., 2008. Good modelling of bad outputs: pollution and multiple-output production.

Førsund, F.R., 1998. Pollution modelling and multiple-output production theory. Dep. Econ. Univ. Oslo.

Franz Fischler, 2002. European Commission - PRESS RELEASES - Press release - Dr. Franz FISCHLER Member of the European Commission responsible for Agriculture, Rural Development and Fisheries Putting our Ideas into Practice Agricultural Policy and Natura 2000 Green Week 2002 Br.

Godoy-Durán, Á., Galdeano- Gómez, E., Pérez-Mesa, J.C., Piedra-Muñoz, L., 2017. Assessing eco-efficiency and the determinants of horticultural family-farming in southeast Spain. J. Environ. Manage. 204, 594-604. doi:10.1016/J.JENVMAN.2017.09.037

GRI, 2015. Sustainability Reporting Guidelinesd G4.

Hampf, B., Rødseth, K.L., 2015. Carbon dioxide emission standards for U.S. power plants: An efficiency analysis perspective. Energy Econ. 50, 140-153. doi:10.1016/J.ENECO.2015.04.001

Hillis, V., Lubell, M., Hoffman, M., 2018. Sustainability partnership and viticulture management in California. J. Environ. Manage. 217, 214-225. doi:10.1016/J.JENVMAN.2018.03.033

Hoang, V.-N., Coelli, T., 2011. Measurement of agricultural total factor productivity growth incorporating environmental factors: A nutrients balance approach. J. Environ. Econ. Manage. 62, 462-474. doi:10.1016/J.JEEM.2011.05.009

Kalsoom, Q., Khanam, A., 2017. Inquiry into sustainability issues by preservice teachers: A pedagogy to enhance sustainability consciousness. J. Clean. Prod. 164, 1301-1311. doi:10.1016/J.JCLEPRO.2017.07.047

Kneese, A. V., Ayres, R.U., D’Arge, R.C., 1970. Economics and the Environment. Johns Hopkins University Press, Washington.

Landorf, C., 2011. Evaluating social sustainability in historic urban environments. Int. J. Herit. Stud. 17, 463-477. doi:10.1080/13527258.2011.563788

Law, K.M.Y., Gunasekaran, A., 2012. Sustainability development in high-tech manufacturing firms in Hong Kong: Motivators and readiness. Int. J. Prod. Econ. 137, 116-125. doi:10.1016/J.IJPE.2012.01.022

Lebacq, T., Baret, P. V, Stilmant, D., 2013. Sustainability indicators for livestock farming. A 
review. Agron. Sustain. Dev. 33, 311-327.

Lee, J.-D., Park, J.-B., Kim, T.-Y., 2002. Estimation of the shadow prices of pollutants with production/environment inefficiency taken into account: a nonparametric directional distance function approach. J. Environ. Manage. 64, 365-375. doi:10.1006/JEMA.2001.0480

Leleu, H., 2013. Shadow pricing of undesirable outputs in nonparametric analysis. Eur. J. Oper. Res. 231, 474-480. doi:10.1016/J.EJOR.2013.05.028

Lozano, R., Nummert, B., Ceulemans, K., 2016. Elucidating the relationship between Sustainability Reporting and Organisational Change Management for Sustainability. J. Clean. Prod. 125, 168-188. doi:10.1016/J.JCLEPRO.2016.03.021

Macombe, C., Leskinen, P., Feschet, P., Antikainen, R., 2013. Social life cycle assessment of biodiesel production at three levels: a literature review and development needs. J. Clean. Prod. 52, 205-216. doi:10.1016/J.JCLEPRO.2013.03.026

Magon, R.B., Thomé, A.M.T., Ferrer, A.L.C., Scavarda, L.F., 2018. Sustainability and performance in operations management research. J. Clean. Prod. doi:10.1016/j.jclepro.2018.04.140

Maletič, M., Maletič, D., Gomišček, B., 2016. The impact of sustainability exploration and sustainability exploitation practices on the organisational performance: a cross-country comparison. J. Clean. Prod. 138, 158-169. doi:10.1016/J.JCLEPRO.2016.02.132

Mariantonietta, F., Alessia, S., Francesco, C., Giustina, P., 2018. GHG and cattle farming: COassessing the emissions and economic performances in Italy. J. Clean. Prod. 172, 37043712. doi:10.1016/J.JCLEPRO.2017.07.167

Missimer, M., Robèrt, K.-H., Broman, G., Sverdrup, H., 2010. Exploring the possibility of a systematic and generic approach to social sustainability. J. Clean. Prod. 18, 1107-1112.

Murphy, K., 2012. The social pillar of sustainable development: a literature review and framework for policy analysis. Sustain. Sci. Pract. Policy 8.

Murty, M.N., Kumar, S., 2002. Measuring the cost of environmentally sustainable industrial development in India: a distance function approach. Environ. Dev. Econ. 7, 467-486. doi:10.1017/S1355770X02000281

Murty, S., Russell, R.R., Levkoff, S.B., 2012. On modeling pollution-generating technologies. J. Environ. Econ. Manage. 64, 117-135. 
Nauges, C., O’Donnell, C.J., Quiggin, J., 2011. Uncertainty and technical efficiency in Finnish agriculture: a state-contingent approach. Eur. Rev. Agric. Econ. 38, 449-467. doi:10.1093/erae/jbr014

Noll, R.G., Trijonis, J., 1971. Mass Balance, General Equilibrium, and Environmental Externalities. Am. Econ. Rev. doi:10.2307/1811870

O’Donnell, C.J., Chambers, R.G., Quiggin, J., 2010. Efficiency analysis in the presence of uncertainty. J. Product. Anal. 33, 1-17.

O’Donnell, C.J., Griffiths, W.E., 2006. Estimating State-Contingent Production Frontiers. Am. J. Agric. Econ. 88, 249-266. doi:10.1111/j.1467-8276.2006.00851.x

O’Donnell, C.J., Rao, D.S.P., Battese, G.E., 2008. Metafrontier frameworks for the study of firmlevel efficiencies and technology ratios. Empir. Econ. 34, 231-255. doi:10.1007/s00181007-0119-4

Pashaei Kamali, F., Meuwissen, M.P.M., de Boer, I.J.M., van Middelaar, C.E., Moreira, A., Oude Lansink, A.G.J.M., 2017. Evaluation of the environmental, economic, and social performance of soybean farming systems in southern Brazil. J. Clean. Prod. 142, 385-394. doi:10.1016/J.JCLEPRO.2016.03.135

Petit, G., Sablayrolles, C., Yannou-Le Bris, G., 2018. Combining eco-social and environmental indicators to assess the sustainability performance of a food value chain: a case study. J. Clean. Prod. doi:10.1016/j.jclepro.2018.04.156

Phelan, A. (Anya), Dawes, L., Costanza, R., Kubiszewski, I., 2017. Evaluation of social externalities in regional communities affected by coal seam gas projects: A case study from Southeast Queensland. Ecol. Econ. 131, 300-311. doi:10.1016/J.ECOLECON.2016.09.010

Rafiaani, P., Kuppens, T., Dael, M. Van, Azadi, H., Lebailly, P., Passel, S. Van, 2018. Social sustainability assessments in the biobased economy: Towards a systemic approach. Renew. Sustain. Energy Rev. 82, 1839-1853. doi:10.1016/J.RSER.2017.06.118

Rajalahti, T., Kvalheim, O.M., 2011. Multivariate data analysis in pharmaceutics: A tutorial review. Int. J. Pharm. doi:10.1016/j.ijpharm.2011.02.019

Sáez-Martínez, F.J., Lefebvre, G., Hernández, J.J., Clark, J.H., 2016. Drivers of sustainable cleaner production and sustainable energy options. J. Clean. Prod. 138, 1-7. doi:10.1016/j.jclepro.2016.08.094

Schreinemachers, P., Tipraqsa, P., 2012. Agricultural pesticides and land use intensification in 
high, middle and low income countries. Food Policy 37, 616-626.

doi:10.1016/j.foodpol.2012.06.003

Sellers-Rubio, R., Nicolau-Gonzalbez, J.L., 2016. Estimating the willingness to pay for a sustainable wine using a Heckit model. Wine Econ. Policy 5, 96-104.

doi:10.1016/J.WEP.2016.09.002

Serra, T., Chambers, R.G., Oude Lansink, A., 2014. Measuring technical and environmental efficiency in a state-contingent technology. Eur. J. Oper. Res. 236, 706-717.

Serra, T., Poli, E., 2015. Shadow prices of social capital in rural India, a nonparametric approach. Eur. J. Oper. Res. 240, 892-903. doi:10.1016/J.EJOR.2014.08.019

Serra, T., Stefanou, S., Lansink, A.O., 2010. A dynamic dual model under state-contingent production uncertainty. Eur. Rev. Agric. Econ. 37, 293-312. doi:10.1093/erae/jbq021

Seuring, S., Müller, M., 2008. From a literature review to a conceptual framework for sustainable supply chain management. J. Clean. Prod. 16, 1699-1710.

doi:10.1016/J.JCLEPRO.2008.04.020

Singbo, A.G., Lansink, A.O., Emvalomatis, G., 2015. Estimating shadow prices and efficiency analysis of productive inputs and pesticide use of vegetable production. Eur. J. Oper. Res. 245, 265-272. doi:10.1016/J.EJOR.2015.02.042

Skevas, T., Serra, T., 2017. Derivation of netput shadow prices under different levels of pest pressure. J. Product. Anal. 48, 25-34. doi:10.1007/s11123-017-0507-5

Staniškienè, E., Stankevičiūtè, Ž., 2018. Social sustainability measurement framework: The case of employee perspective in a CSR-committed organisation. J. Clean. Prod. 188, 708-719. doi:10.1016/J.JCLEPRO.2018.03.269

Tang, C.S., 2018. Socially responsible supply chains in emerging markets: Some research opportunities. J. Oper. Manag. 57, 1-10. doi:10.1016/J.JOM.2018.01.002

Thompson, C.D., Wiggins, M., 2002. The human cost of food : farmworkers' lives, labor, and advocacy. University of Texas Press.

Thomsen, K., King, M.C., 2008. 10 Working out Social Sustainability on the Ground. Underst. Soc. Dimens. Sustain. 199.

Unay-Gailhard, İ., Bojnec, Š., 2016. Sustainable participation behaviour in agri-environmental measures. J. Clean. Prod. 138, 47-58. doi:10.1016/J.JCLEPRO.2015.09.003 
Van Calker, K.J., Berentsen, P.B.M., De Boer, I.J.M., Giesen, G.W.J., Huirne, R.B.M., 2007. Modelling worker physical health and societal sustainability at farm level: an application to conventional and organic dairy farming. Agric. Syst. 94, 205-219.

Vanni, F., 2014. Agriculture and Public Goods, in: Agriculture and Public Goods. Springer Netherlands, Dordrecht, pp. 1-19. doi:10.1007/978-94-007-7457-5_1

Varela-Candamio, L., Calvo, N., Novo-Corti, I., 2018. The role of public subsidies for efficiency and environmental adaptation of farming: A multi-layered business model based on functional foods and rural women. J. Clean. Prod. 183, 555-565. doi:10.1016/J.JCLEPRO.2018.02.109

Vintró, C., Sanmiquel, L., Freijo, M., 2014. Environmental sustainability in the mining sector: evidence from Catalan companies. J. Clean. Prod. 84, 155-163. doi:10.1016/J.JCLEPRO.2013.12.069

Wang, S., Chu, C., Chen, G., Peng, Z., Li, F., 2016. Efficiency and reduction cost of carbon emissions in China: a non-radial directional distance function method. J. Clean. Prod. 113, 624-634. doi:10.1016/J.JCLEPRO.2015.11.079

Welch, E., Barnum, D., 2009. Joint environmental and cost efficiency analysis of electricity generation. Ecol. Econ. 68, 2336-2343. doi:10.1016/J.ECOLECON.2009.03.004

Whetten, D.A., 1989. What Constitutes a Theoretical Contribution? Acad. Manag. Rev. 14, 490495. doi:10.5465/AMR.1989.4308371

Wilson, C., Tisdell, C., 2001. Why farmers continue to use pesticides despite environmental, health and sustainability costs. Ecol. Econ. 39, 449-462. doi:10.1016/S0921-8009(01)002385

Xiao, C., Wang, Q., van der Vaart, T., van Donk, D.P., 2018. When Does Corporate Sustainability Performance Pay off? The Impact of Country-Level Sustainability Performance. Ecol. Econ. 146, 325-333. doi:10.1016/J.ECOLECON.2017.11.025

Xie, H., Shen, M., Wei, C., 2016. Technical efficiency, shadow price and substitutability of Chinese industrial SO2 emissions: a parametric approach. J. Clean. Prod. 112, 1386-1394. doi:10.1016/J.JCLEPRO.2015.04.122 